\title{
CORRESPONDENCE
}

\section{THE ECONOMICS OF SHIPPING IN POLAR SEAS}

As subscribers through many years to Polar Record we wish to compliment you on the high quality of your magazine and on the many interesting articles and reports on science and enterprise in the polar regions.

We were, however, astonished to read the article The economics of shipping in polar seas by Thornton A. Sherman, in the Polar Record Vol 14, No 91, 1969 , p 478.87 which purports to illustrate the profitability of polar ships in general, and of our Dan-polar ships in particular, detailing construction costs, operating expenses and income in a manner that might convince the non-expert reader.

We do not know Mr Sherman, nor his sources of information, but we are sorry to say that he is either badly informed or must have misinterpreted or miscomputed information.

He states that the operating expenses of a heavily ice-strengthened Dan-class vessel of 2000 tons dw are virtually the same as for a conventional ship of the same size.

If, however, Mr Sherman is referring to our Thala Dan and Nella Dan-class of 2130 and 2200 tons dw respectively, strengthened far beyond Ice Class 1 , accommodating up to about forty-five expedition members besides the crew of thirty to thirty-two, fitted with heavy lifts, refrigerated space, extra fuel tanks, helicopter deck, double radar and echo sounder sets, etc, the figures shown in the article in regard to building costs and operating expenses are very considerably below the actual figures. Neither is correct in so far as the Dan-ships are concerned that the charterer pays the extra insurance for trading outside Institute Warranty Limits. With one exception only we are paying the extra insurance in the Arctic as well as in the Antarctic.

We think we can best illustrate how far out of line Mr Sherman's figures are by referring to his figure for the total wages and social security expenses for twenty-four officers and men per month of US $\$ 3420$. This gives an average of US $\$ 142.50$ per man per month. In the early 1960's a Danish AB fetched about 35 per cent more excluding social security, and apart from the fact that our polar expedition vessels have a larger crew, the ten officers of course fetched much more.

The hull (casco) insurance premium, excluding extras for trading outside the Institute Warranty Limits, at that time was more than 15 (fifteen) times higher than stated by $\mathrm{Mr}$ Sherman. According to his article the yearly premium $(12 \times \$ 180)$ should be 0.155 per cent. The author must have misunderstood or miscomputed information received from Messrs. Osborne and Lange, insurance brokers, Montreal, listed under "References".

Mr Sherman in his article also mentions our Anita Dan, and in relation to the extra insurance payable for trading this vessel outside Institute Warranty Limits refers to the Anita Dan as being strengthened to a lesser degree than 
Ice Class 2. The Anita Dan (since acquired by the British Government) is strengthened beyond Ice Class 1 , so here again his pieces of information are wrong.

As $\mathrm{Mr}$ Sherman is thus grossly underestimating costs of the ships as well as operating expenses, and is on the high side in regard to income, the return on investment in polar ships he arrives at is also wrong-and unfortunately very much wrong. He is suggesting that he has found proof of his pretentions in the fact that about one fourth of our total fleet consists of polar vessels. This was so, but due to the development of the polar markets, where these vessels have to make their living, we have had to adjust our polar fleet downwards to the 40000 tons $\mathrm{dw}$ it comprises today, which is only about 13 per cent of our total fleet.

J. LAURITZEN

KøBENHAVN

23 April 1969
JØRGEN CLAUSEN Assistant Managing DiRector 